\title{
THE SELECTIVE ACCUMULATION OF BLOOD PROTEINS BY THE OOCYTES OF SATURNIID MOTHS
}

\author{
WILLIAM H. TELFER 1 \\ Zoological Laboratory, University of Pennsylvania, Philadelphia 4, Penna.
}

The growing oocyte of an insect accumulates proteins from the blood, rather than relying exclusively on the synthetic activities of the ovaries. Wigglesworth (1942) demonstrated in a number of blood-sucking insects that the modified hemoglobin which occurs in the oocytes is derived from the blood. More recently, an immunologically detected protein occurring in the blood of female saturniid moths has been found to leave the blood during the maturation of the ovaries and to accumulate in the oocytes (Telfer, 1954). That such a process might be entailed in the growth of oocytes other than those of insects is suggested by the antigenic and physical similarities between oocyte and serum proteins of chickens (Schechtman, 1947 ; Nace, 1953; Schjeide and Urist, 1956) and of frogs (Cooper, 1948; Flickinger and Rounds, 1956).

A variety of other animal cells can accumulate soluble proteins from their environment and, of these, one of the most thoroughly analyzed has been the amoeba (Holter, 1959). The mechanism of protein uptake in the amoeba has been proposed to include two essential features: adsorption of the protein on the surface of the cell (Marshall, Schumaker and Brandt, 1959), and a subsequent infolding of the cell surface to form vacuoles (Mast and Doyle, 1934; Chapman-Andresen and Prescott, 1956). The latter process was first described by Lewis (1931) who observed mammalian cells in tissue culture ingesting their culture medium.

An analysis of protein accumulation by the moth oocyte has been undertaken. Included in this analysis is an attempt to determine whether the mechanism involved is comparable to that proposed for the amoeba. Since, unlike the amoeba, the moth oocyte cannot be observed microscopically during the process of protein accumulation, studies of the mechanism must in this case be based on less direct methods. Evidence is presented here that most proteins in the blood of the moth enter the oocyte to some extent but that, from a quantitative point of view, the mechanism is highly selective. The bearing of this and other evidence on the nature of the protein accumulating mechanism will be considered in later papers.

\section{Materials And Methods}

The capacities of seven proteins to enter the oocytes from the blood of the Polyphemus moth were assayed by means of a quantitative application of Oudin's antiserum-agar technique. Two of the proteins occur in the blood of the Cecropia moth and normally accumulate in the oocyte of that species. This has already been demonstrated for one protein, which will be referred to as the "female protein,"

1 This work was performed in part while the author was a Summer Fellow of the Lalor Foundation, and in part with the support of Phi Beta Psi Sorority. 
and it is demonstrated here for a second protein found in the blood. The five additional proteins were derived from the blood or oocytes of animals other than insects.

\section{Injection of foreign proteins}

The protein preparations were introduced into diapausing female pupae of the Polyphemus moth which had previously been chilled for several months at $6^{\circ} \mathrm{C}$. in order to activate the endocrine mechanism responsible for stimulating their transformation into moths (Williams, 1956). The Cecropia proteins were introduced into pupae by the transfusion technique previously described (Telfer, 1954). Proteins of non-insectan origins were injected into the haemocoel from a tuberculin syringe through a No. 28 hypodermic needle. The volume of the protein solution, in milliliters, was equal to one-twentieth of the weight of the pupa in grams, in the case of the non-insectan proteins, and to one-fifth of the weight of the pupa in the case of Cecropia blood. In order to avoid melanin formation which can occur in the blood in response to surgical schock, approximately $0.1 \mathrm{mg}$. of phenylthiourea was included in the solution introduced into each animal.

\section{Preparation of the blood and oocyte fluid of Polyphemus moths}

Oocyte growth occurs in Polyphemus primarily during the final half of the period of transformation of the pupa into the moth. The injected animals were bled at the end of this period. The blood was collected in test tubes and stored under mineral oil at $-20^{\circ} \mathrm{C}$. The ovaries were thoroughly washed with 0.15 $M \mathrm{NaCl}$, blotted and placed in a mortar. Most of the oocytes were shaken free of the ovarioles during the washing procedure, and the chorions of these oocytes were broken by pressure applied with a pestle. The yolky contents that were thus squeezed out of the chorions were centrifuged at $20,000 \times g$ for thirty minutes at $0^{\circ} \mathrm{C}$. After centrifugation, a clear, yellow, aqueous layer, which will be referred to as oocyte fluid, lay between a sediment and a floating, particulate layer. The clarified oocyte fluid occupied approximately three-quarters of the volume of the centrifuged oocyte contents. It was analyzed, along with the blood, for its content of the protein in question. Melanin formation was prevented in both blood and oocyte fluid by the addition of crystalline phenylthiourea.

\section{Preparation of the protein solutions for injection into Polyphemus pupae}

Commercial preparations of chicken ovalbumin, bovine gamma globulin and bovine serum albumin (all Pentex) were dissolved in $0.15 \mathrm{M} \mathrm{NaCl}$ at neutral $\mathrm{pH}$. A $2 \%$ solution of a protein preparation was used for injection into pupae.

In addition, extracts of chicken's egg yolk and of lobster oocytes were studied. The chicken yolk extracts were prepared by washing several yolks free of the white and then breaking them in several times their volume of $0.15 \mathrm{M} \mathrm{NaCl}$. The mixture was dialyzed against saline solution and finally centrifuged at $20,000 \times g$. The final preparation, which was an opalescent yellow solution, was injected into pupae without further dilution. Judging from the ionic strength of the extraction medium, this preparation should have included the protein complexes, lipovitellenin and livetin (Fevold, 1951). 
Lobster oocytes were obtained from ovaries dissected from living lobsters (Homarus americanus). Developing lobster oocytes, after passing through yellow and pale green phases, finally attain a dark green color. The oocytes extracted here were at least $2 \mathrm{~mm}$. in diameter and were dark green. They were loosened from the ovarian wall by agitation in $0.15 \mathrm{M} \mathrm{NaCl}$. After being washed several times, the oocytes were disintegrated in a Virtis homogenizer in several times their volume of saline solution. The extract, after dialysis against saline and centrifugation at $20,000 \times g$, was a clear, dark green solution. The green color of lobster oocytes is due to ovoverdin, the carotenoid-protein complex studied by Stern and Salomon (1937).

Finally, two proteins of Cecropia blood were studied. These were initially discovered by means of immunological techniques and were designated as antigens 3 and 7 (Telfer and Williams, 1953). Polyphemus pupae were transfused with whole blood of Cecropia female pupae, which contains both of these proteins.

Most of the non-insectan protein solutions and extracts studied were toxic to some of the injected pupae and in these cases death occurred within three days after the injection. Such pupae never initiated their development into moths. The surviving animals, on the other hand, transformed into moths in the usual three-week period of time. Their ovaries produced eggs which appeared to be normal in size and structure, although sometimes reduced in number. Three preparations, bovine fibrinogen, phosvitin from hen's eggs and hemocyanin from lobster blood, were toxic to all pupae injected, and efforts to study the uptake of these proteins by the oocytes were therefore abandoned.

\section{Immunological procedures}

Antisera were obtained from rabbits. The reaction between a protein and its antibodies was studied by means of the antiserum-agar technique developed by Oudin (1948) and previously applied to the study of insect blood and oocyte proteins (Telfer and Williams, 1953; Telfer, 1954). A rabbit antiserum was solidified with agar in glass tubes $(3 \mathrm{~mm}$. i.d.) and was then overlayered with the blood, oocyte fluid or other sample whose content of the homologous protein was being tested. The antiserum was diluted to an appropriate level with 0.15 $M \mathrm{NaCl}$ buffered at $\mathrm{pH}$ 7.0. The rate of advance of the zone of antigen-antibody precipitation through the antiserum-agar (distance travelled/square root of time) was used as an index to the concentration of the protein serving as the antigen. The rate of advance of a zone of precipitation was converted to the relative concentration of the corresponding protein in the antigen layer by reference to a standard curve. Standard curves were constructed for each protein studied by determining the rate of advance of the zone of precipitation produced by a series of dilutions of a solution of the protein.

Precautions were taken which were previously recommended (Preer and Telfer, 1957) for reducing the effects of substances not involved in the reaction on the rate of advance of the zone of precipitation: in order to eliminate errors due to viscosity differences, the composition of the antiserum-agar was kept constant in any set of tests; and all tests were set up so that convection mixing occurred in the antigen layer (tubes vertical, antigen layer above the antiserum-agar, and the density of the antigen layer greater than that due to the diffusible components of the antiserum-agar). 
In addition, it was demonstrated that samples of oocyte fluid, blood and 0.15 $M \mathrm{NaCl}$, which were known to contain equal concentrations of an antigen, produced zones of precipitation with the same rates of advance (Table I). Therefore, with the exception of possible special cases, the Oudin test as applied here provided a valid criterion for comparing antigen concentrations in the blood and oocyte fluid of the moth.

\section{Antigenic characteristics of the foreign proteins}

All of the preparations of non-insectan proteins, except the lobster oocyte extract, on reacting in Oudin tubes with a $1: 3$ dilution of their homologous antisera produced a single dense zone of precipitation and, in several cases, additional weak zones. In order to achieve maximum sensitivity for the detection of

TABLE I

Comparison of the oocyte fluid and blood of Polyphemus moths as solvents for ovalbumin in antiserum-agar tests. Antigen solutions were layered over a 1:3 dilution of anti-ovalbumin serum

\begin{tabular}{|c|c|c|c|}
\hline \multirow{2}{*}{$\begin{array}{l}\text { Dilution of a } 2 \% \text { ovalbumin } \\
\text { solution in antigen layer }\end{array}$} & \multicolumn{3}{|c|}{ Rate of advance of the zone of precipitation when ovalbumin was diluted with } \\
\hline & Oocyte fluid & Blood & $0.15 M \mathrm{NaCl} *$ \\
\hline $\begin{array}{l}1: 1 \\
1: 2 \\
1: 4 \\
1: 8 \\
1: 16 \\
1: 32 \\
1: 64 \\
1: 128 \\
1: 256\end{array}$ & $\begin{array}{c}\times 10^{-3} \text { cm.-sec. }{ }^{-\frac{1}{2}} \\
3.2 \\
2.9 \\
2.7 \\
2.5 \\
2.2 \\
1.9 \\
1.6 \\
1.3 \\
1.1\end{array}$ & $\begin{array}{c}\times 10^{-3} \mathrm{~cm} . \text {-sec. }^{-\frac{1}{2}} \\
3.2 \\
3.1 \\
2.8 \\
2.5 \\
2.2 \\
1.9 \\
1.6 \\
1.3 \\
1.1\end{array}$ & $\begin{array}{c}\times 10^{-3} \mathrm{~cm} . \text {-sec. }^{-\frac{1}{2}} \\
\frac{3.3}{2.8} \\
\frac{-}{2.2} \\
\frac{-}{1.7} \\
\frac{-1}{1.1}\end{array}$ \\
\hline
\end{tabular}

* Since $0.15 \mathrm{M} \mathrm{NcCl}$ is less dense than the $1: 3$ dilution of antiserum, the Oudin tubes were placed horizontally in this case in order to assure convection in the antigen layer.

these antigens in Polyphemus blood and oocyte fluid, the antisera were diluted as much as was consistent with a clear visualization of the densest zone of precipitation. As a result, the weaker zones were generally not visible and information was thus obtained concerning only the antigen producing the densest zone. Two dense zones were visible in the reaction between the lobster oocyte extract and its homologous antiserum. Since the densities and rates of advance of these two zones were extremely similar, they were treated as a single zone and the rate of advance was determined only for the faster of the pair.

\section{Results}

1. Demonstration of an oocyte antigen which is indistinguishable from a carotenoid protein of the blood

Evidence that Cecropia oocytes contain a protein which is antigenically similar to the female protein of the blood was described earlier (Telfer, 1954). Ob- 
servations are described here which indicate that, in addition to the female protein, one of the several carotenoid proteins of the blood also has an antigenic counterpart in the oocyte.

Adult antiserum $d$, a pooled antiserum obtained from three rabbits which had been immunized with an extract of Cecropia female moths, produced two zones of dense precipitation when overlayered in Oudin tubes with either the oocyte fluid or the blood of female moths. One of these zones was not ordinarily produced by male blood and was thus identifiable as resulting from the precipitation of antigen 7 , the female protein. The second, more slowly moving zone was due to precipitation of a substance previously designated as antigen 3 and characterized as a carotenoid protein. This identity was established in mutual dilution tests (Telfer and

\section{TABLE II}

The rates of advance of the two major zones of precipitation appearing when antiserum-agar containing adult anti-serum d (1:3) was overlayered with graded mixtures of oocyte fluid and the blood of female pupae

$\begin{array}{ccc}\begin{array}{c}\text { Composition of the } \\ \text { antigen layer } \\ \left(\frac{\% \text { blood }}{\% \text { oocyte fluid }}\right)\end{array} & \begin{array}{c}\text { Rate of advance of the zone of precipitation due to } \\ \text { Carotenoid protein }\end{array} \\ \frac{100}{0} & 2.01 \times 10^{-3} \text { cm.-sec. }^{-\frac{1}{2}} & 1.26 \times 10^{-3} \mathrm{~cm}_{\text {- }} \text { sec. }^{-\frac{1}{2}} \\ \frac{87.5}{12.5} & 2.04 & 1.29 \\ \frac{75}{25} & 2.11 & 1.29 \\ \frac{50}{50} & 2.17 & 1.35 \\ \frac{25}{75} & 2.23 & 1.41 \\ \frac{12.5}{87.5} & 2.23 & 1.44 \\ \frac{0}{100} & 2.28 & 1.49\end{array}$

Williams, 1953) in which aliquots of a sample of pupal blood were layered over graded mixtures of adult antiserum $d$ and adult antiserum $a$, the antiserum whose reaction initially distinguished the carotenoid protein.

That the two zones of dense precipitation produced by oocyte fluid, on the one hand, and female blood, on the other, were due to related antigens was indicated by the results of mutual dilution tests. When graded mixtures of pupal female blood and oocyte fluid were layered over adult antiserum $d$, the two zones of dense precipitation behaved as shown in Table II. The rate of advance of each zone shifted gradually from that in the tube containing only blood to that containing only oocyte fluid. There was no detectable splitting, fusion, or crossing of the two zones. With regard to the precipitations visible in these tests, one can 
therefore conclude that, as in the case of the female protein zone, the antibodies which form a single zone of precipitation with a carotenoid protein of the blood also form a single zone of precipitation with an antigen diffusing from the oocyte fluid.

Absorption tests provided additional evidence that the oocyte fluid contains an antigen similar to the carotenoid protein of the blood. Immunization of four rabbits with oocyte fluid and of three rabbits with female pupal blood led in every case to the production of antibodies which, according to mutual dilution tests with adult antiserum $d$, precipitated both the female and carotenoid proteins of the blood. All of these antisera, on absorption with an equal volume of a $1: 10$ dilution of

TABLE III

Absorption of antisera against Cecropia oocyte fluid with the blood of female pupae

\begin{tabular}{|c|c|c|c|c|}
\hline \multirow{3}{*}{$\begin{array}{c}\text { Antiserum } \\
\text { (final dilution } \\
1: 3 \text { in all cases) }\end{array}$} & \multicolumn{4}{|c|}{ Zones of precipitation produced when oocyte fluid was layered over agar containing } \\
\hline & \multicolumn{2}{|c|}{ Unabsorbed antiserum } & \multicolumn{2}{|c|}{ Antiserum absorbed with blood of female pupae } \\
\hline & $\begin{array}{l}\text { Intensity of } \\
\text { precipitation }\end{array}$ & Rate of advance & $\begin{array}{l}\text { Intensity of } \\
\text { precipitation }\end{array}$ & Rate of advance \\
\hline Oocyte fluid $a$ & $\begin{array}{l}\text { Weak } \\
\text { Strong* } \\
\text { Strong** }\end{array}$ & $\begin{array}{c}\times 10^{-3} \mathrm{~cm}_{.- \text {sec. }^{-\frac{1}{2}}} \\
2.17 \\
2.04 \\
1.16\end{array}$ & $\begin{array}{l}\text { Weak } \\
\text { Weak } \\
\text { Weak }\end{array}$ & $\begin{array}{c}\times 10^{-3} \mathrm{~cm}_{.-\mathrm{sec}} \mathrm{-}^{-\frac{1}{2}} \\
2.20 \\
1.24 \\
0.81\end{array}$ \\
\hline Oocyte fluid $b$ & $\begin{array}{l}\text { Weak } \\
\text { Strong* } \\
\text { Strong** }\end{array}$ & $\begin{array}{l}2.26 \\
1.59 \\
1.36\end{array}$ & $\begin{array}{l}\text { Weak } \\
\text { Weak }\end{array}$ & $\begin{array}{l}2.19 \\
1.55\end{array}$ \\
\hline Oocyte fluid $c$ & $\begin{array}{l}\text { Weak } \\
\text { Strong* } \\
\text { Weak } \\
\text { Strong** }\end{array}$ & $\begin{array}{l}2.17 \\
2.10 \\
1.36 \\
0.99\end{array}$ & Weak & 2.31 \\
\hline Oocyte fluid $d$ & $\begin{array}{l}\text { Weak } \\
\text { Strong* } \\
\text { Strong** }\end{array}$ & $\begin{array}{l}2.30 \\
1.52 \\
1.25\end{array}$ & Weak & 2.39 \\
\hline
\end{tabular}

* Zone of precipitation of the female protein (antigen 7 ).

** Zone of precipitation of the carotenoid protein (antigen 3 ).

oocyte fluid, lost their capacity to precipitate either blood or oocyte antigens in Oudin tests. Thus the oocyte fluid contains antigenic counterparts of all the substances, including the carotenoid and female proteins, detected in the blood with these four antisera.

Absorption of the antisera with female blood led to different results. As would be anticipated, the absorption of female blood antisera with pupal female blood removed all of the antibodies visibly precipitating either blood or oocyte antigens in Oudin tests. However, antisera against oocyte fluid, after absorption with female blood, retained the capacity to form from one to three zones of weak precipitation when overlayered by oocyte fluid (Table III). 
Absorption tests thus indicated that the oocyte contains, in addition to the blood antigens precipitated by these antisera, at least three antigens which have not been detected in pupal female blood. The fastest zone produced when oocyte fluid reacted with the blood-absorbed antisera had, in each case, an intensity and rate of advance similar to the fastest zone produced by the unabsorbed antiserum. Oocyte antisera $a$ and $b$ produced additional zones whose failure to appear in the reactions with unabsorbed antisera was probably due to masking by the faster and denser zone of female protein precipitation (Table III). An alternative possibility of interest to the present problem is that at least one of these zones could have been due to residual antibodies against the oocyte's carotenoid protein-antibodies whose failure to react with the carotenoid protein of the blood would thus indicate an antigenic difference between the carotenoid proteins of the blood and of the oocyte. If this were the case, however, the amount of antibody involved was small in comparison with the total amount of carotenoid protein antibodies present in unabsorbed antiserum. The weak zones produced by a $1: 3$ dilution of the unabsorbed antiserum were comparable in intensity to the carotenoid protein precipitation in 1:30 dilutions of unabsorbed antiserum. Thus, at least 90\% and possibly all of the antibodies precipitated by the carotenoid protein of the oocyte were also precipitated by the carotenoid protein of the blood.

Mutual dilution and absorption tests therefore led to the conclusion that the oocyte fluid contains a substance which is antigenically similar to and probably identical with antigen 3 , a carotenoid protein of the blood.

\section{The relative concentrations of the carotenoid and female proteins in the oocyte} fluid and the blood of Cecropia moths

The concentrations of the carotenoid and female proteins in both the oocyte fluid and the blood were estimated from the rates of advance of their respective zones of precipitation. When the oocyte fluid and blood collected simultaneously from the same moth were layered over a $1: 3$ dilution of oocyte antiserum $c$ in Oudin tubes, the zones of carotenoid protein precipitation advanced through the antiserum-agar at approximately equal rates. The zone of female protein precipitation advanced through the agar considerably faster from the oocyte fluid than from the blood, a result which is in accord with earlier observations on the female protein zone and which can be attributed to a disparity in concentration of this protein between the blood and the oocyte fluid (Telfer, 1954). Reference of the rates of advance of these zones of precipitation to standard curves yielded the relative antigen concentrations summarized in Table IV. This interpretation of the rates of advance led to the conclusion that the carotenoid protein is approximately equally concentrated in the oocyte fluid and blood of the thoths, while the femael protein is, on the average, twenty-eight times more concentrated in the oocyte fluid than in the blood.

\section{The accumulation of Cecropia blood proteins by Polyphemus oocytes}

Evidence that the carotenoid protein of the oocyte has its origin in the blood, rather than being synthesized in the ovary, was obtained from experiments in which the blood of Cecropia pupae was injected into female Polyphemus pupae. 
TABLE IV

Relative concentrations of the female and carotenoid proteins in the oocyte fluid and in the blood of female Cecropia moths

\begin{tabular}{|c|c|c|c|c|c|c|}
\hline \multirow{2}{*}{ Animal no. } & \multicolumn{2}{|c|}{$\begin{array}{l}\text { Relative concentration of } \\
\text { female protein }\end{array}$} & \multicolumn{2}{|c|}{$\begin{array}{l}\text { Relative concentration of } \\
\text { carotenoid protein }\end{array}$} & \multicolumn{2}{|c|}{$\begin{array}{l}\text { Concentration ratio } \\
\left(\frac{\text { oocyte fluid }}{\text { blood }}\right)\end{array}$} \\
\hline & Oocyte fluid & Blood & Oocyte fluid & Blood & Fem. prot. & Carot. prot. \\
\hline 1 & 1.15 & 0.03 & 1.00 & 0.77 & 38 & 1.3 \\
\hline 2 & 0.93 & 0.03 & 0.85 & 0.81 & 38 & 1.1 \\
\hline 3 & 1.05 & 0.06 & 1.45 & 1.25 & 18 & 1.2 \\
\hline 4 & 0.90 & 0.04 & 0.81 & 0.81 & 21 & 1.0 \\
\hline 5 & 0.76 & 0.03 & - & - & 29 & - \\
\hline 6 & 1.15 & 0.04 & 0.66 & 1.20 & 31 & 1.8 \\
\hline 7 & 1.05 & 0.06 & 1.12 & 1.20 & 19 & 1.9 \\
\hline \multirow[t]{2}{*}{8} & 1.05 & 0.03 & 0.71 & 1.35 & 37 & 0.5 \\
\hline & & & & Mean & 28 & 1.1 \\
\hline
\end{tabular}

When these animals had transformed into moths, their oocyte fluid and blood were obtained and were layered over adult antiserum $d$ which had previously been absorbed with the blood of Polyphemus female pupae. After absorption in this manner, the antiserum retained its capacity to produce its two major zones of precipitation when overlayered with female Cecropia pupal blood, although, due to the removal of some antibodies, the zones were somewhat reduced in intensity. Thus Polyphemus blood contains substances which are antigenically similar to both the female and carotenoid proteins of Cecropia but which are distinctive enough so that they are unable to precipitate all of the antibodies against the Cecropia proteins.

Studies of the amount of the two Cecropia proteins in Polyphemus blood or oocyte fluid require that the rate of advance of the Cecropia protein's zone of

TABLE V

The relative concentrations of Cecropia's carotenoid and female proteins in the oocyte fluid and blood of Polyphemus female moths

\begin{tabular}{|c|c|c|c|c|c|c|}
\hline \multirow{2}{*}{ Animal no. } & \multicolumn{2}{|c|}{$\begin{array}{l}\text { Relative concentration of } \\
\text { female protein }\end{array}$} & \multicolumn{2}{|c|}{$\begin{array}{l}\text { Relative concentration of } \\
\text { carotenoid protein }\end{array}$} & \multicolumn{2}{|c|}{$\begin{array}{l}\text { Concentration ratio } \\
\left(\frac{\text { oocyte fluid }}{\text { blood }}\right)\end{array}$} \\
\hline & Oocyte fluid & Blood & Oocyte fluid & Blood & Fem. prot. & Carot. prot. \\
\hline 1 & 1.1 & 0.05 & 1.0 & 0.7 & 22 & 1.4 \\
\hline 2 & 1.1 & 0.05 & 0.5 & 0.6 & 22 & 1.0 \\
\hline 3 & 1.5 & 0.05 & 0.8 & 0.7 & 30 & 1.1 \\
\hline 4 & 0.7 & 0.05 & 0.8 & 0.4 & 14 & 2.0 \\
\hline \multirow[t]{2}{*}{5} & 1.0 & 0.05 & 0.4 & 0.8 & 20 & 0.5 \\
\hline & & & & Mean & 21 & 1.2 \\
\hline
\end{tabular}


precipitations be unaffected by the Polyphemus proteins present in the antigen layer. This requirement was found to be fulfilled: the blood of Polyphemus female pupae was indistinguishable from $0.15 M \mathrm{NaCl}$ as a diluent for the two Cecropia antigens reacting with the Polyphemus-absorbed antiserum. Thus, the Oudin test could be used to indicate not only the presence, but also the concentrations of these two Cecropia proteins in Polyphemus moths.

Both the blood and the oocyte fluid of Polyphemus moths which had been transfused with Cecropia blood produced the two characteristic zones of dense precipitation in Oudin tests with the Polyphemus-absorbed adult antiserum $d$. The carotenoid and female proteins of Cecropia therefore found their way into the Polyphemus oocytes from the blood, an observation which has already been reported for the female protein.

When the rates of advance of the two zones of precipitation were converted to the relative concentrations of their respective antigens, the results recorded in Table $\mathrm{V}$ were obtained. The distribution of Cecropia's female and carotenoid proteins between the blood and oocytes of Polyphemus was approximately the same as their normal distribution in Cecropia (Table IV). This result suggests that neither the carotenoid protein nor the female protein of the oocyte fluid is synthesized in appreciable amounts in the ovary, but that both are derived primarily, and perhaps exclusively, from the blood.

\section{Similarities between other antigens of the oocyte fluid and blood}

The demonstration that the carotenoid and female proteins of the oocyte fluid are derived primarily from the blood raises the question as to whether other blood proteins participate in oocyte formation. The reactions of Cecropia oocyte fluid with adult antiserum $a$ and with larval antiserum $c$ suggest that this is the case. These two antisera have been shown to react with a minimum of six different Cecropia blood proteins, one of which is the carotenoid protein studied here (Telfer and Williams, 1953). In Oudin tests, each antiserum produced up to seven zones of precipitation when overlayered by Cecropia oocyte fluid. After absorption with equal volumes of a 1:10 dilution of oocyte fluid, none of the antisera was able to produce zones of precipitation when overlayered with Cecropia pupal blood. Substances which are antigenically similar to at least five blood proteins, in addition to the female and cartenoid proteins, are therefore present in the oocyte fluid. This result is consistent with the possibility that many, or even all, of the proteins normally present in the moth's blood enter the oocyte fluid to some extent, although synthesis in the ovary has not yet been ruled out in all these cases.

\section{The accumulation of non-insectan proteins by Polyphemus oocytes}

Less equivocal evidence that the oocytes can accumulate blood proteins other than the female and carotenoid proteins was obtained from experiments in which five antigens which are completely foreign to the moth were injected into the blood. Neither the blood nor the oocyte fluid of uninjected moths produced zones of precipitation in Oudin tests with antisera against the five non-insectan antigens studied. Therefore, the appearance of the antigenic activity of the injected protein preparations in the oocyte fluid could be interpreted as due to accumulation from the blood, rather than to synthesis in the ovary. 
Of the five antigens injected into Polyphemus pupae, four were detectable in Oudin tests in both the blood and the oocyte fluid of the subsequently emerging moths. Only the major antigenic component of the chicken's yolk extract was undetectable in the oocyte fluid. The conclusion thus seems warranted that most proteins present in the blood are accumulated to some extent by the oocyte.

The relative concentrations of the foreign antigens in the oocyte fluid and blood were estimated from the rates of advance of their zones of precipitation (Table VI). The concentration of Cecropia's female protein in Polyphemus oocyte fluid, relative to its concentration in the blood at the conclusion of egg formation, was approximately 200 times greater than that of the non-insectan proteins. Thus, while

\section{TABLE VI}

Relative concentrations of foreign antigens in the oocyte fluid and blood of Polyphemus moths

\begin{tabular}{l|c|c|c}
\hline \hline \multicolumn{1}{c|}{ Antigen } & \multicolumn{2}{|c|}{ Concentration ratio (oocyte fluid/blood) } & $\begin{array}{c}\text { Number } \\
\text { of cases }\end{array}$ \\
\cline { 2 - 3 } & Mean & Range & 5 \\
\hline Cecropia female protein & 21 & $14-30$ & 5 \\
Cecropia carotenoid protein & 1.2 & $0.5-2.0$ & 6 \\
Bovine gamma globulin & 0.19 & $0.08-0.60$ & 7 \\
Bovine serum albumin & 0.07 & $0.06-0.11$ & 4 \\
Ovalbumin & 0.07 & $0.04-0.13$ & 7 \\
Lobster oocyte antigen (probably ovoverdin) & 0.10 & $0.06-0.16$ & 4 \\
Chicken yolk antigen (probably lipovitellenin) & Undetectable in & $0.03-0.20$ & \\
& oocyte fluid & & \\
\hline
\end{tabular}

most proteins in the blood appear to enter the oocyte to some extent, different proteins vary greatly in their capacity to do so.

\section{Localization of the blood proteins within the oocyte}

The oocyte fluid analyzed in the Oudin tests described here consisted primarily of a solution derived from the breakdown of the yolk bodies. When whole oocytes were centrifuged at $20,000 \times g$, the strata which were formed within the chorion appeared different from the strata produced by the centrifugation of crushed oocytes. While a centripetal layer presumably consisting of fatty materials was formed in both cases, a non-particulate intermediate layer comparable to the clarified yellow fluid of crushed oocytes was not produced in whole oocytes. More than $90 \%$ of the volume of centrifuged whole oocytes was occupied by a sediment which, on dissection, was seen to consist of yellow spheres whose diameter ranged up to greater than 20 microns. Since more than three-quarters of the volume of crushed oocytes forms a clear, yellow liquid on centrifugation, it appears that the yellow spheres of undamaged oocytes are liquified when the eggs are crushed with a mortar and pestle. The nature of these particles, which we presume to be the yolk spheres of the cytologists (Wilson, 1925), will be considered in more detail in a later paper.

While the oocyte fluid presumably contained the non-particulate ooplasm and 
fractions of any less voluminous particles which may have been damaged when the yolk was being expressed from the chorion, its primary constituent must have been lysed or liquified yolk spheres. The possibility thus appears that the proteins derived from the blood may be localized in the yolk spheres of the oocyte. This proposal is confirmed by the fact that the yolk spheres are colored bright yellow, for at least one of the proteins found here to be accumulated by the oocyte is a carotenoid protein which contributes to the yellow color of the blood.

\section{Discussion}

The oocytes of saturniid moths have now been demonstrated to accumulate the female protein and a carotenoid protein from the blood. Antigenic similarities between the oocyte fluid and the blood suggest that other proteins which normally occur in the insect's blood may also be accumulated by the oocyte, although in these cases synthesis within the ovary has not been excluded. In addition, four proteins of non-insectan origin, after injection into the blood, have been found in the oocyte. Thus far, the only protein which has not been detected in the oocyte after injection into the blood is one derived from chicken yolk extract. Whether some feature of the uptake mechanism prevents the accumulation of this molecule or whether, in the course of accumulation, its antigenic properties are destroyed has not been determined. In experiments similar to some of those described here, Knight and Schechtman (1954) demonstrated that foreign proteins pass from the serum to the ovum of chickens.

There are large differences in the quantitative distribution of the various proteins between the oocyte fluid and blood. The data (Table VI) suggest that the mechanism of accumulation is uniquely adapted to the removal of particular proteins from the blood, and that others, such as the non-insectan proteins injected into the pupa may, in effect, be carried into the oocyte as contaminants. This interpretation presumes that the oocyte fluid: blood concentration ratios measured here are determined primarily by the capacity of the protein in question to penetrate the various cellular layers of the ovary and the surface of the oocyte. However, other events occurring within the injected insect could also affect this ratio and these must be considered in any attempt to apply the ratio of concentrations to an analysis of the protein accumulating mechanism.

Structural alterations which occurred in a protein molecule during or after its entry into the oocyte could, by affecting the rate of advance of the corresponding zone of precipitation, lead to gross errors in determinations of its distribution ratio. Such alterations could act in two ways: by altering the protein's antigenic properties and thus its capacity to combine with antibodies, or by altering its diffusion coefficient. A significant alteration in antigenic properties during the accumulation of the carotenoid and female proteins can be ruled out, since as is shown here, the blood and oocyte representatives of these proteins are extremely similar, and are possibly identical in their capacity to precipitate antibodies. It is also unlikely that the antigenic activities of the non-insectan proteins studied were grossly modified during their accumulation by the oocytes. In these cases, the zones of precipitation produced by the blood and oocyte fluid of the injected animals appeared to be equally dense and thus to entail the precipitation of comparable amounts of antibody. Antigenic changes which might not have been detectable by 
this criterion could not account for the 200 -fold differences observed in the oocyte fluid: blood concentration ratios of the proteins studied here. In a later paper, data will be presented which indicate that a change in diffusion coefficient does not occur during the transfer of either the female or carotenoid protein from the blood to the oocyte. It is therefore improbable that the distribution ratios measured for the seven proteins under consideration were subject to errors resulting from molecular alterations associated with the process of accumulation. Knight and Schechtman (1954) found that, in the chicken also, foreign proteins injected into the serum were not detectably altered by transmission to the ovum.

A protein's distribution between oocyte fluid and blood could be affected by secondary processes which are unrelated to the transfer mechanism: processes such as adsorption on an insoluble structure in the oocyte, or a selective destruction in the blood or other tissues after accumulation by the oocyte has been completed. While such processes may occur to some extent, the following observations indicate that the difference between the oocyte fluid:blood concentration ratios of the female and carotenoid proteins does in fact reflect a difference in their capacity to penetrate the oocyte. During the period of maximal oocyte growth, the concentration of female protein in the blood decreases $80 \%$, while that of the carotenoid protein decreases only 20-25\% (Telfer and Rutberg, 1960) - a difference which is readily accounted for by the female protein's being removed from the blood at a faster rate than the carotenoid protein. In addition, selective accumulation of the female protein can explain the effects of ovariectomy on the blood of female moths (Telfer, 1954). The electrophoretic pattern of the blood of moths which had been ovariectomized as pupae was similar to that of the blood of normal moths except for the fact that the moths which had not been allowed to produce eggs contained excessive amounts of a component possessing the electrophoretic mobility of the female protein. Comparisons of the female and carotenoid proteins thus established that the moth oocyte does not accumulate all proteins in proportion to their concentrations in the blood, but that the transport mechanism is characterized by a high degree of selectivity.

Selectivity of accumulation suggests that the protein transport mechanism may be more complex than could be accounted for alone by free diffusion from the blood to the oocyte. In two other cases of protein transport, it has been necessary to conclude that a protein combines temporarily with some element of the transport mechanism. Such a step has been postulated in order to explain the selectivity and competition demonstrated in the transmission of maternal antibodies to the foetus and the new-born of a number of species of mammals (Brambell, Halliday and Morris, 1958). In addition, adsorption of protein on the surface of an amoeba undergoing pinocytosis is convincingly suggested by kinetic and cytological evidence (Schumaker, 1958; Brandt, 1958).

Several mechanisms could be proposed to account for the selectivity of protein accumulation by the oocyte of the moth. Included among these is a temporary adsorption on the cell surface, as has been proposed for the amoeba. Adsorption on an intracellular structure such as the yolk spheres is not ruled out, however, nor is selective permeability of one of the various cellular envelopes which separate the oocyte from the blood. Distinguishing which of these possibilities may be correct must await further characterization of the uptake mechanism. 
A final point which the protein accumulating mechanism of the moth oocyte may have in common with that of the amoeba is the intracellular disposition of the acquired protein. In both cases, the protein is associated to a major extent with cytoplasmic particles: pinocytic vacuoles in the amoeba and yolk spheres in the oocyte. Proteins with the antigenic properties of serum proteins are also associated with the yolk platelets of the amphibian oocyte (Cooper, 1948; Flickinger and Rounds, 1956). It may thus prove possible to establish a homology between these cytoplasmic structures with regard to their function in protein accumulation from the environment.

\section{Summary}

1. At least seven proteins detectable by immunological techniques in the blood of the Cecropia moth have antigenic counter-parts in the oocytes produced by the female moth. While several oocyte antigens are undetectable in the blood of the female pupa, all of the proteins thus far observed in the blood are also present in the oocyte. Four out of five proteins of non-insectan origins, after being injected into the blood of the Polyphemus moth were detectable in the oocyte. Thus, the oocyte appears to accumulate almost all of the proteins present in the blood.

2. When the blood of Cecropia is injected into females of the Polyphemus moth, antigen 7 , the "female protein," and antigen 3, a carotenoid protein, become distributed between the blood and the oocytes of the host in a manner quantitatively similar to their normal distribution in Cecropia. These two oocyte proteins may therefore be derived exclusively from the blood, rather than being synthesized to an appreciable extent in the ovary. The capacity of these proteins to combine with homologous antibodies was not detectably altered during their transmission from the blood to the oocyte.

3. Measurements of the concentrations of several proteins in the oocyte, relative to their concentrations in the blood, indicate that the mechanism of protein accumulation is selective. Of the proteins studied, the female protein was the most avidly accumulated, while the non-insectan proteins were detectable in the oocyte in relatively small amounts.

4. The proteins derived from the blood are probably localized primarily in the yolk spheres of the oocyte. Protein accumulation in this case therefore entails both the penetration of the oocyte surface and association with a cytoplasmic particle.

\section{LITERATURE CITED}

Brambell, F. W. R., R. Halliday and I. G. Morris, 1958. Interference by human and bovine serum and serum protein fractions with the absorption of antibodies by suckling rats and mice. Proc. Roy. Soc. London, Series B, 149: 1-12.

Brandt, P. W., 1958. A study of the mechanism of pinocytosis. Exp. Cell Res., 15: 300-313.

Chapman-Andresen, C., and D. Prescott, 1956. Pinocytosis in the amoeba, Chaos chaos and Amoeba proteus. Compt. Rend. Trav. Lab. Carlsberg. Ser. Chim., 30: 57-78.

Cooper, R. S., 1948. A study of frog egg antigens with serum-like reactive groups. J. Exp. Zool., 107: 397-437.

Fevold, H. L., 1951. Egg proteins. Advances in Protein Chemistry, 6: 188-252.

Flickinger, R. A., And D. E. Rounds, 1956. The maternal synthesis of egg yolk proteins as demonstrated by isotopic and serological means. Biochim. et Biophys. Acta, 22: $38-42$.

Holter, H., 1959. Problems of pinocytosis, with special regard to Amoebae. Ann. N. Y. Acad. Sci., 78: 524-537. 
Knight, P. T., And A. M. Schechtman, 1954. The passage of heterologous serum proteins from the circulation into the ovum of the fowl. J. Exper. Zool., 127 : 271-304.

Lewis, W. H., 1931. Pinocytosis. Johns Hopkins Hosp. Bull., 49: 17-27.

Marshall, J. M., V. N. Schumaker and P. W. Brandt, 1959. Pinocytosis in amoebae. Ann. N. Y. Acad. Sci., 78 (Art. 2) : 515-523.

Mast, S. O., and W. L. Doyle, 1934. Ingestion of fluid by amoeba. Protoplasma, 20: 555560.

Nace, G. W., 1953. Serological studies of the blood of the developing chick embryo. J. Exp. Zool., 122: 423-448.

Oudin, J., 1948. L'analyse immunochimique qualitative; methods par diffusion des antigenes au sein de l'immunserum precipitant gelose. Ann. Anat. Pasteur, 75: 30-52; 109-130.

Preer, J. R., And W. H. Telfer, 1957. Some effects of non-reacting substances in the quantitative application of gel diffusion techniques. J. Immunol., 79: 288-293.

Schechtmann, A. M., 1947. Antigens of early developmental stages of the chick. J. Exp. Zool., 105: 329-348.

Schjeide, O. A., And M. R. Urist, 1956. Proteins and calcium in serums of estrogen-treated roosters. Science, 124: 1242-1244.

Schumaker, V. N., 1958. Uptake of protein from solution by Amoeba proteus. Exp. Cell Res., 15: 314-331.

Stern, K. G., and K. Salomon, 1937. Ovoverdin, a pigment chemically related to visual purple. Science, 86: 310-311.

Telfer, W. H., 1954. Immunological studies of insect metamorphosis. II. The role of a sex-limited blood protein in egg formation by the Cecropia silkworm. J. Gen. Physiol., 37: 539-558.

Telfer, W. H., and L. D. Rutberg, 1960. The effects of blood protein depletion on the growth of the oocytes in the Cecropia moth. Biol. Bull., 118: 352-366.

Telfer, W. H., and C. M. Williams, 1953. Immunological studies of insect metamorphosis. I. Qualitative and quantitative changes in the blood proteins of the Cecropia silkworm. J. Gen. Physiol., 36: 389-413.

Wigglesworth, V. B., 1942. The fate of haemoglobin in Rhodnius prolixus (Hemiptera) and other blood-sucking arthropods. Proc. Roy. Soc. London, Series B, 131: 313-339.

Williams, C. M., 1956. Physiology of insect diapause. X. An endocrine mechanism for the influence of temperature on the diapausing pupa of the Cecropia silkworm. Biol. Bull., 110: 201-218.

Wilson, E. B., 1925. The Cell in Development and Heredity. The Macmillan Company, New York. 


\section{$2 \mathrm{BHL}$ Biodiversity Heritage Library}

Telfer, William H. 1960. "The selective accumulation of blood proteins by the oocytes of saturniid moths." The Biological bulletin 118, 338-351. https://doi.org/10.2307/1539007.

View This Item Online: https://www.biodiversitylibrary.org/item/110976

DOI: https://doi.org/10.2307/1539007

Permalink: https://www.biodiversitylibrary.org/partpdf/2140

\section{Holding Institution}

Smithsonian Libraries

\section{Sponsored by}

Biodiversity Heritage Library

\section{Copyright \& Reuse}

Copyright Status: In copyright. Digitized with the permission of the rights holder.

License: http://creativecommons.org/licenses/by-nc-sa/3.0/

Rights: https://biodiversitylibrary.org/permissions

This document was created from content at the Biodiversity Heritage Library, the world's largest open access digital library for biodiversity literature and archives. Visit BHL at https://www.biodiversitylibrary.org. 